\title{
PROTUPONUDITELJSKE MJERE PREMA NACRTU ZAKONA O IZMJENAMA I DOPUNAMA ZAKONA O PREUZIMANJU DIONIČKIH DRUŠTAVA
}

Prof. dr. sc. Petar Miladin*

\author{
UDK 347.72(497.5)(094) \\ https://doi.org/10.30925/zpfsr.39.3.7 \\ Ur.: 23. ožujka 2018. \\ Pr.: 28. svibnja 2018. \\ Pregledni znanstveni rad
}

\begin{abstract}
Sažetak
Zakon o preuzimanju dioničkih društava zahtijeva reformu, a u svakom slučaju bar otvorenu javnu raspravu, o položaju uprave i nadzornog odbora odnosno upravnog odbora ciljnog dioničkog društva u postupku preuzimanja ciljnog društva. Ministarstvo financija osnovalo je Radnu skupinu koja raspravlja i priprema Nacrt Zakona o izmjenama i dopunama Zakona o preuzimanju dioničkih društava. Autor kao član radne skupine zauzima stajalište o reformi prava preuzimanja dioničkih društava u dijelu koji se tiče poduzimanja protuponuditeljskih mjera u postupku preuzimanja dioničkih društava te nudi konkretne prijedloge. Razlozi za zaokret temelje se na kritici tvrdoga neutralnog položaja uprave i nadzornog odbora ciljnog društva de lege lata. Ističe se da je kruto pravilo čl. 42. st. 1. ZPDD-a o tzv. neutralnom položaju uprave $i$ nadzornog odbora ciljnog društva u postupku preuzimanja derogiralo temeljno pravilo o vođenju poslova društva iz čl. 252. Zakona o trgovačkim društvima. Spomenuto pravilo treba stoga izmijeniti tako da se u najvećoj mogućoj mjeri uvaže vrijednosti domaćeg prava društava i prava tržišta kapitala. Radikalno isključenje temeljnog standarda vođenja poslova društva u postupku preuzimanju de lege lata nije opravdano. Posebice nije primjereno sa stajališta odmjeravanja međusobno suprotstavljenih pravnopolitičkih interesa. Dobrobit ciljnog društva ne smije se praktički potpuno zatrti zbog tobože prečih interesa prava preuzimanja dioničkih društava. De lege lata dobrobit ciljnog društva nije, najblaže rečeno, dovoljno vrednovana u postupku preuzimanja te se (u tom smislu) nude rješenja de lege ferenda. Dobar primjer za potreban pravnopolitički i pozitivnopravni zaokret nude odredbe njemačkog Wertpapiererwerbs- und Übernahmegesetz (nadalje WpÜG) po uzoru na koja je autor ponudio rješenja de lege ferenda. Direktiva 2004/25 EU o ponudama za preuzimanje počiva u tom dijelu na opcijskom modelu.
\end{abstract}

* Dr. sc. Petar Miladin, redoviti profesor Pravnog fakulteta Sveučilišta u Zagrebu; petar.miladin@, pravo.hr. 


\begin{abstract}
Ključne riječi: pravo preuzimanja dioničkih društava, protuponuditeljske mjere, pravni položaj uprave i nadzornog odbora, načelo neutralnosti, obveza uprave voditi poslove društva.
\end{abstract}

\title{
1. $U V O D$
}

Nacrt Zakona o izmjenama i dopunama Zakona o preuzimanju dioničkih društava (Narodne novine, br. 109/07, 36/09, 108/12, 90/13 i 148/13, nadalje ZPDD) sazrio je za javnu raspravu bar u dijelu koji se tiče promjene paradigme položaja uprave i nadzornog odbora ciljnog društva u postupku preuzimanja. Autor rada napisao je kao član Radne skupine Ministarstva financija koja raspravlja i priprema Nacrt Zakona o izmjenama i dopunama ZPDD-a (Odluka KLASA: 011-01/16-01/22 URBROJ: 513-06-03-16-2 od 5. svibnja 2016., nadalje Radna skupina) taj dio Nacrta Zakona o izmjenama i dopunama ZPDD-a te ga je u ovom radu, uz za to potrebna obrazloženja, dao na uvid zainteresiranoj javnosti, a za potrebe dokumentiranja posla koji je do sad u tom dijelu odradila Radna skupina. Cilj je zainteresirati javnost za teme o kojima je Radna skupina raspravljala na svojim redovitim sjednicama, kritizirati stanje de lege lata glede položaja uprave i nadzornog odbora u postupku preuzimanja te iznijeti argumente u prilog svojih prijedloga. Dosadašnje rasprave i materijali Radne skupine svakako su dragocjena građa za izučavanje prava preuzimanja dioničkih društava koje se razvilo u posebnu specijaliziranu pravnu disciplinu. ${ }^{1}$

Problem položaja uprave i nadzornog odbora ciljnog društva te nastavno na to protuponuditeljskih mjera nije jedina tema koja zaokuplja pozornost Radne skupine.

1 Glede literature iz područja prava preuzimanja dioničkih društava v. Čulinović-Herc, E., Zubović, A., Pravne značajke provedenih postupaka preuzimanja prije i nakon pristupanja u EU i uočena regulatorna pitanja, Zbornik Pravnog fakulteta u Zagrebu, 66, (5) str. 619-638 (2016); Čulinović-Herc, E., Mikinac, O., Otvorena pitanja uvrštenih dioničkih društava: razlozi za i protiv povlačenja vrijednosnih papira s uvrštenja na uređenom tržištu, u: ČulinovićHerc, E., Jurić, D., Žunić Kovačević, N. (ured.), Zbornik radova s konferencije „Financiranje, upravljanje i restrukturiranje trgovačkih društava u doba recesije“, Rijeka, 2011., str. 92; Ivkošić, M., Obrana dioničkog društva od neprijateljskog preuzimanja, doktorski rad, Zagreb, 2013.; Ivkošić, M., Gubitak prava glasa - sankcija zbog povrede odredbi o obavješćivanju odnosno preuzimanju dioničkih društava, Zbornik susreta pravnika, Zagreb, 2017., str. 345-380; Parać, Z., Dileme oko preuzimanja javnih dioničkih društava, PuG 2003/4, str.35-56; Miladin, P., Trgovina financijskim instrumentima (vrijednosnim papirima, efektima), u: Miladin, P. (ur.) Prilagodba hrvatskog prava i ekonomije europskom tržištu kapitala, Zagreb, 2013., str. 527 i nadalje; Zubović, A., Stjecanje glasačke kontrole nad uvrštenim društvom, doktorski rad, Zagreb, 2012.; Jurić, D., Zubović, A., Protuponuditeljske mjere i položaj uprave ciljnog društva u postupku preuzimanja ciljnog društva, Zbornik Pravnog fakulteta Sveučilišta u rijeci, vol. 30., br. 1. 2009., str. 326.

Za njemačko pravo v. Steinmeyer, R., WpÜG Wertpapiererwerbs- und Übernahmegesetz Kommentar, 3. potpuno izmijenjeno i dopunjeno izdanje, Berlin, 2013.; Hirte, H., Büllow, C. (ur.), Kölner Kommentar zum WpÜG, 2. izmijenjeno i dopunjeno izdanje, Köln, 2010.

Radna skupina nije izašla službeno sa svojim Nacrtom Zakona o izmjenama i dopunama ZPDD-a, tako da je ovdje predloženi Nacrt Zakona o izmjenama i dopunama ZPDD-a za sad autorov prijedlog koji je sam i izradio. Autor se zalaže, dakle, da to bude Nacrt Zakona o izmjenama i dopunama ZPDD-a Radne skupine, u dijelu protuponuditeljskog djelovanja. 
Među potencijalnim prijedlozima ističe se rasprava o sustavu privatnopravnih i upravno-prekršajnopravnih sankcija prema preuzimatelju koji povrijedi svoje prisilnopravne obveze propisane ZPDD-om. Sve te sankcije treba sagledati sa stajališta odluka Ustavnog suda Republike Hrvatske koji se već u dva navrata izjašnjavao o ustavnosti ključne sankcije gubitka prava glasa koja pogađa preuzimatelje povrijede li oni svoje kogentne obveze propisane ZPDD-om. Ustavni sud Republike Hrvatske u odlukama od 22. studenog 2006. te od 8. i 9. srpnja 2013. naložio je Hrvatskom saboru da uskladi zakonska rješenja za koja je taj sud ocijenio da nisu u suglasnosti s Ustavom, a tiču se ponajprije sankcije isključenja prava glasa. ${ }^{2}$ To bitno pitanje nadilazi, međutim, opseg $i$ temu ovog rada te u tom dijelu treba uputiti na bogatu domaću i poredbenu književnost koja se njime bavi te općenito pitanjima iz područja prava preuzimanja dioničkih društava. Treba, međutim, i ovom prilikom naglasiti da pretežu razlozi da se sankciju gubitka prava glasa zadrži u čl. 5. ZPDD-a te da u tom smislu Vlada Republike Hrvatske kao predlagatelj Nacrta Zakona o izmjenama i dopunama ZPDD-a treba posebno voditi računa da se dobro argumentira zašto tu sankciju treba zadržati, a da se pritom uvaže svi standardi ustavnosti kojih se zakonodavac dužan pridržavati. To se, posebice, treba staviti u kontekst odustanka od paralelne privatnopravne sankcije obveznog sklapanja ugovora o kupoprodaji dionica između preuzimatelja i dioničara ciljnog društva de lege ferenda.

\section{OSVRT NA TRENUTNO STANJE I KRATAK PRIKAZ PREDLOŽENIH PROMJENA}

Svaka rasprava o tzv. „neprijateljskim“ ponudama za preuzimanje svodi se u konačnici na sukob interesa između dioničara ciljnog društva, $s$ jedne strane, i samog ciljnog društva, s druge. Interes dioničara ciljnog društva je financijske prirode. Ponuda za preuzimanje prilika je da dioničar ciljnog društva što bolje unovči svoje dionice; bolje nego što bi ih inače unovčio da ih prodaje preko burze da nema preuzimanja. Uprava i nadzorni odbor ciljnog društva dužni su, pak, skrbiti o interesima društva. Posrijedi nisu samo interesi dioničara ciljnog društva, riječ je, također, i o skrbi za interese svih, tzv. dionika dioničkog društva, stakeholdera (dioničara, vjerovnika ciljnog društva, radnika, države, jedinica lokalne samouprave i uprave, ukupne društvene zajednice na koju može utjecati djelatnost društva). Interes, dobrobit ciljnog društva ne svodi se u svakom slučaju samo na ekonomske interese dioničara, pa je uprava u svom djelovanju dužna štititi i interese svih ostalih dionika dioničkog društva. Odredba čl. 41. ZPDD-a o tomu jasno vodi računa, ${ }^{3}$ no odredba čl. 42. ZPDD-a ne daje upravi prostor da se suprotstavi čak ni očitim neprijateljskim namjerama ponuditelja.

2 Odluke Ustavnog suda Republike Hrvatske broj: U-I-977/2004 od 22. studenog 2006., broj: U-I-4468/2008 i od 8. srpnja 2013. te broj: U-I-2479/2100 i od 9. srpnja 2013.

3 Tamo je jasno propisano da se uprava ciljnog društva treba izjasniti o namjeri ponuditelja glede budućeg poslovanja ciljnog društva, strateškim planovima ponuditelja i posljedicama provedbe tih planova na politiku zapošljavanja i trenutne radnike ciljnog društva, kao i na moguće promjene vezane za mjesta u kojima društvo posluje. 
Iluzorno je očekivati da će se dioničari ciljnog društva u pravilu masovno rukovoditi interesima dobrobiti ciljnog društva odnosno ukupne društvene zajednice kad su stavljeni pred izbor hoće li prodati dionice ciljnog društva po za njih primamljivoj cijeni ili će, pak, zadržati svoje dionice i tako zaštititi preče interese dobrobiti ciljnog društva koji su ugroženi konkretnim neprijateljskim ponudama za preuzimanje. Iskustvo govori, da će dioničari ciljnog društva u pravilu podrediti interese dobrobiti ciljnog društva svojim privatnim ekonomskim interesima, osim ako se pravnopolitičkom intervencijom ne osigura ravnoteža između interesa dobrobiti ciljnog društva, na jednoj strani, i privatnih ekonomskih interesa dioničara ciljnog društva, na drugoj. Dobra ponuda za kupnju dionica jednostavno se ne otklanja zbog prečih interesa društva.

Sukob interesa zaoštrava se dodatno budući da članovi uprave mogu u postupku preuzimanja štititi i svoje vlastite, privatne interese. Sprječavanje ili ometanje preuzimanja ostavlja barem dozu sumnje da uprava pritom ne postupa samo u interesu društva, već i kako bi zadržala svoj utjecaj pa i svoj goli položaj, opstanak u ciljnom društvu. Ne smije se stoga nekritički paušalno ovlastiti upravu ciljnog društva na poduzimanje protuponuditeljskih mjera. Uprava ciljnog društva može, međutim, s druge strane, nekritički pospješivati ponude za preuzimanje koje inače objektivno nisu u interesu ciljnog društva. Proaktivnim, ali i nekritičkim pasivnim držanjem u postupku preuzimanja, uprava je kadra u svom vlastitom privatnom interesu poticati rast odnosno pad cijene dionica ciljnog društva. O tomu je riječ ako uprava ciljnog društva na temelju svojih opcijskih prava (engl. stock options) ima priliku kalkulirati kad joj je najpovoljnije stjecati, odnosno otuđivati dionice ciljnog društva. Atraktivne ponude za preuzimanje kadre su itekako primamiti članove uprave ciljnog društva. One se, štoviše, često i daju nakon što je to prethodno dogovoreno s članovima uprave ciljnog društva. ${ }^{4}$ Članovi uprave su osobno zainteresirani za uspjeh ponude za preuzimanje ako njihovi menadžerski ugovori sadrže, tzv. Change-of-control klauzulu koja članovima uprave daje pravo da im društvo, dođe li do preuzimanja isplati sva primanja koja su preostala do isteka tog važećeg ugovora te da s njima sklopi novi ugovor koji će im dati bitno veća primanja. ${ }^{5}$ Čl. 42. st. 4. Nacrta ZPDD-a zabranjuje ponuditelju i osobama koje s njim zajednički djeluju davati odnosno nuditi, činiti izglednom članovima uprave i nadzornog odbora ciljnog društva nedopuštenu novčanu činidbu i bilo kakvu drugu nedopuštenu imovinsku korist kako bi time zadobili njihovo savezništvo u postupku preuzimanja ciljnog društva. Ta je odredba sročena po uzoru na odgovarajuće pravilo § 33d njemačkoga WpÜG-a.

Budući da se države članice EU-a pri donošenju Direktive 2004/25 EU o ponudama za preuzimanje (nadalje Direktiva 2004/25 EU) nisu usuglasile s izrazito blagonaklonim shvaćanjem Europske komisije o tomu da je postupak preuzimanja dioničkih društava apsolutno pozitivan ekonomski i društveni fenomen o uspjehu kojega su jedino i isključivo ovlašteni odlučivati dioničari ciljnog društva, čl. 12. Direktive 2004/25 EU propisao je opcijski model koji državama članicama EU-a nudi da pri usklađivanju svojih prava s njenim zahtjevima odstupe od usvajanja

4 Hirte, H., op. cit. u bilj. 1, § 33 rbr. 22.

5 Hirte, H., op. cit. u bilj. 1, § 33 rbr. 22. 
blagonaklonog prisilnopravnog europskog koncepta neutralnosti glede uređenja pravnog položaja uprave i nadzornog odbora u postupku preuzimanja dioničkih društava (tzv. opt out). Države članice EU-a kadre su odstupiti od europske paradigme uređenja pravnog položaja uprave i nadzornog odbora u postupku preuzimanja, samo ako su se ciljna dionička društva pojedine države članice EU-a kadra sama, na temelju odredbi svojih statuta, podvrgnuti prethodno isključenom europskom konceptu neutralnosti glede uređenja pravnog položaja uprave i nadzornog odbora u postupku preuzimanja dioničkih društava (tzv. opt in). Dođe li do zaokreta u pravnopolitičkom pristupu položaju uprave i nadzornog odbora ciljnog društva u postupku preuzimanja; iskoristi li se, dakle, mogućnost propisana čl. 12. Direktive EU 2004/25 i otkloni europsko ograničenje djelovanja uprave i nadzornog odbora ciljnog društva - koje je de lege lata usvojeno u kogentnom čl. 42. ZPDD-a! - (opt out), europsko ograničenje djelovanja uprave i nadzornog odbora ciljnog društva treba urediti isključivo na dobrovoljnoj osnovi odnosno odgovarajućim odredbama statuta ciljnog društva (opt in).

Nacrt Zakona o izmjenama i dopunama ZPDD-a ide za tim da hrvatsko pravo iskoristi, tzv. opt out, tako što će se važeći koncept ograničenja djelovanja uprave i nadzornog odbora ciljnog društva zamijeniti novim s tim da će se istodobno novim čl. 43. Nacrta Zakona o izmjenama i dopunama ZPDD usvojiti i tzv. opt in koncept koji će dioničkim društvima omogućiti da se podvrgnu trenutačno kogentno važećem, tzv. europskom ograničenju djelovanja uprave i nadzornog odbora ciljnog društva iz čl. 42. ZPDD. Isključi li se statutom ciljnog društva primjena čl. 42. Nacrta Zakona o izmjenama i dopunama ZPDD-a, primijenit će se automatizmom, ex lege, odredbe čl. 43. stavka 2. Nacrta ZPDD-a, odnosno tzv. europsko ograničenje djelovanja uprave $i$ nadzornog odbora ciljnog društva. Nema dakle posebne potrebe da statuti dioničkih društva nakon što isključe primjenu odredbe čl. 42. ZPDD-a posebno uređuju konkretna ograničenja uprave i nadzornog odbora iz čl. 43. st. 2. ZPDD-a, jer će se ona tada ionako primijeniti ipso iure. Odredba čl. 43. Nacrta Zakona o izmjenama i dopunama ZPDD-a je, dakle, u biti na opcijskoj razini konkretnoga ciljnog društva preuzela pravila trenutno važećeg čl. 42. ZPDD-a. Europsko ograničenje djelovanja uprave i nadzornog odbora ciljnog društva usvaja se novim čl. 43. prema Nacrtu Zakona o izmjenama i dopunama ZPDD-a. Tom se odredbom u slučajevima preuzimanja stavljaju izvan snage tipična sprječavanja preuzimanja te se time olakšava preuzimanje. Odredbe čl. 42. i 43. Nacrta ZPDD-a sročene su po uzoru na odgovarajuće odredbe $\S \S 33,33 a$ i 33d njemačkoga WpÜG-a. Ključna novina je odredba čl. 42. Nacrta Zakona o izmjenama i dopunama ZPDD-a koja polazi od njemačkog koncepta obrane od neprijateljskog preuzimanja koji je propisan $\S 33$ WpÜG-a. Rješenje iz čl. 42. st. 3. Zakona o izmjenama i dopunama ZPDD-a propisano je i u $\S 33$ d njemačkoga WpÜG-a.

Odredbe čl. 43. i 44. važećega ZPDD-a uklopljene su u odredbu čl. 44. Nacrta Zakona o izmjenama i dopunama ZPDD-a. Članak 44. Nacrta Zakona o izmjenama i dopunama ZPDD-a prepušta se dioničkim društvima da svojim statutima urede i, tzv. pravilo proboja; europsko pospješenje postupka preuzimanja ciljnog društva. ZPDD zadržava, dakle, važeće rješenje u odnosu na europsko pravilo proboja. Spomenuto 
pravilo primjenjuje se i nadalje, sukladno Nacrtu Zakona o izmjenama i dopunama ZPDD-a, odluče li dioničari ugraditi pravilo proboja u statut svog društva. Činjenica da novi pravni režim postupanja uprave i nadzornog odbora u postupku preuzimanja nadomješta dosadašnje pravilo neutralnosti uprave i nadzornog odbora ne mijenja pritom ništa na stvari. Odgovarajuće rješenje sadrži § 33b njemačkoga WpÜG-a.

Važenje europskog uređenja preuzimanja može se na temelju čl. 44.a Nacrta Zakona o izmjenama i dopunama ZPDD vezati uz uvjet da je i ponuditelj podvrgnut odgovarajućem uređenju (tzv. pravilo uzajamnosti). Članak 12. st. 3. Direktive 2004/25 EZ predviđa, naime, tzv. pravila o reciprocitetu, uzajamnosti. Ta pravila dopuštaju konkretno hrvatskom zakonodavcu osigurati da se primjena europskog ograničenja djelovanja uprave i nadzornog odbora ciljnog društva iz čl. 43. i 44. ZPDD-a ne odraze pogubno na ona hrvatska ciljna društva koja su jače i opsežnije podvrgnuta primjeni europskog ograničenja djelovanja uprave i nadzornog odbora ciljnog društva iz čl. 43. i 44. ZPDD-a nego što je to slučaj s ponuditeljem odnosno nacionalnim pravom koje je za njega mjerodavno. Odgovarajuće rješenje rješenju iz čl. 44.a Nacrta Zakona o izmjenama i dopunama ZPDD-a ima i njemački § 33c WpÜG-a. Taj prijedlog ide za tim da se osigura ravnopravan položaj ciljnih društava sa sjedištem u RH s inozemnim trgovačkim društvima i na unutarnjem tržištu EU-a. ${ }^{6}$

Budući da je čl. 42. ZPDD-a de lege ferenda sukladno Nacrtu Zakona o izmjenama i dopunama ZPDD-a iskoristio pravo da RH odstupi od europskog ograničenja uprave i nadzornog odbora u postupku preuzimanja te europskog prava proboja, prijedlozi čl. 43., 44. i 44.a ZPDD-a su de lege ferenda sukladno Nacrtu Zakona o izmjenama i dopunama ZPDD-a komponente europskog opcijskog modela sukladno čl. 12. Direktive 2004/25 EZ-a. U tu svrhu dobrovoljnog omogućavanja europskog ograničenja djelovanja uprave i nadzornog odbora ciljnog društva i europskog pravila proboja predlažu se de lege ferenda odredbe čl. 43., 44. i 44.a ZPDD-a. Članak 43. ZPDD de lege ferenda sukladno Nacrtu Zakona o izmjenama i dopunama ZPDD-a propisuje rješenje iz čl. 12. st. 2., a u vezi s čl. 9. Direktive 2004/25 EZ, čl. 44. propisuje rješenje iz čl. 12. st. 2., a u vezi s čl. 11. Direktive 2004/25 EZ-a, a čl. 44.a rješenja iz čl. 12. st 3. Direktive 2004/25 EZ-a. Nacrt Zakona o izmjenama i dopunama ZPDD-a je u tom smislu usklađen u cijelosti sa zahtjevima Direktive 2004/25 EZ, a po uzoru na nama, pored područja prava preuzimanja, i u području prava društava i prava tržišta kapitala poredbeno njemačko pravo.

Odredba čl. 42. st. 1. rečenica 2. treća alternativa ZPDD de lege ferenda propisuje kao ključnu iznimku od načela neutralnosti uprave ciljnog društva u ponudbenom razdoblju slučaj kada uprava ciljnog društva poduzima radnje s kojima se suglasio nadzorni odbor ciljnog društva. Prirodno je stoga da mišljenje o ponudi za preuzimanje osim uprave dade i nadzorni odbor. Zbog toga su u tom smislu predložene i izmjene čl. 41. ZPDD-a, a po uzoru na $\S 27$ njemačkog WpÜG-a. Zahtjevno razdoblje ponude za preuzimanje nameće potrebu da se o njoj izjasni u svakom slučaju i nadzorni odbor ciljnog društva, a ne samo njegova uprava kao što je to slučaj de lege lata.

Nacrtom Zakona o izmjenama i dopunama ZPDD-a dodana je u čl. 59.

6 U tom smjeru v. i Zubović, A., op. cit. u bilj. 1, str. 101. V. i Jurić, D., Zubović, A., op. cit. u bilj. 1, str. 326 . 
ZPDD-a nova točka 20. kojom je prekršajnopravno sankcionirano protuponuditeljsko djelovanje članova uprave u ponudbenom razdoblju, osim ako takvo djelovanje nije bilo obuhvaćeno jednom od iznimaka iz čl. 42. st. 1. druga rečenica ZPDD-a de lege ferenda. Ta se odredba predlaže po uzoru na odgovarajuću odredbu $\S 60$ st. 1. t. 8 . njemačkog WpÜG-a. Prijedlog Nacrta Zakona o izmjenama i dopunama ZPDD-a potvrđuje da cilj reforme nije da se upravi ciljnog društva otvore vrata širokog nekritičkog protuponuditeljskog djelovanja. Uprava treba u svakom slučaju voditi računa o tomu da se bez daljnjega treba u pravilu suzdržati od protuponuditeljskog djelovanja, osim ako iznimno nisu prisutne iznimke koje bi bile kadre opravdati njeno drukčije djelovanje. Isti prekršaj počinit će članovi uprave ciljnog društva na koje se primjenjuje europski koncept ograničenja djelovanja uprave i nadzornog odbora ciljnog društva iz čl. 43. Nacrta Zakona o izmjenama i dopunama ZPDD-a poduzmu li mjere suprotno čl. 43. st. 2. i 3. Nacrta Zakona o izmjenama i dopunama ZPDD-a.

ZPDD propisuje de lege lata dva koncepta ograničenja djelovanja uprave i nadzornog odbora ciljnog društva u ponudbenom razdoblju. Posrijedi je prvi uvjetno rečeno dispozitivni zakonski koncept europskog ograničenja djelovanja uprave i nadzornog odbora ciljnog društva u ponudbenom razdoblju iz čl. 42. ZPDD-a koji se može zamijeniti samo još liberalnijim opcijskim europskim pravilom proboja iz čl. 43. i 44. ZPDD-a koje dodatno favorizira postupak preuzimanja ciljnog društva i to ako se u statut ciljnog društva unesu odredbe propisane čl. 44. st. 2. ZPDD-a.

ZPDD propisuje de lege ferenda tri pravna režima ograničenja djelovanja uprave i nadzornog odbora u ponudbenom razdoblju. Prvi je dispozitivan zakonski koncept ograničenja djelovanja uprave i nadzornog odbora ciljnog društva u ponudbenom razdoblju iz čl. 42. ZPDD-a de lege ferenda, koji je u odnosu na trenutačno važeći koncept ublažen s dvije dodatne iznimke iz čl. 42. st. 1. druga rečenica ZPDD-a de lege ferenda te trećom dodatnom iznimkom iz čl. 42. st. 2. ZPDD-a po kojoj glavna skupština smije dati prethodno ovlaštenje upravi da poduzima protuponuditeljske mjere. Potraga za drugim, konkuretskim ponuditeljima ostaje i nadalje iznimka od ograničenja djelovanja uprave i nadzornog odbora ciljnog društva te u tom smislu neće doći do izmjene ni dopune ZPDD-a. Dva trenutačna režima ograničenja djelovanja uprave i nadzornog odbora postaju prema Nacrtu Zakona o izmjenama i dopunama ZPDD-a opcijski koncepti. Koncept europskog ograničenja djelovanja uprave i nadzornog odbora primijenit će se ex lege isključi li se statutom konkretnog dioničkog društva primjena čl. 42. de lege ferenda. Njega ne treba, dakle, dodatno posebno propisati statutom ciljnog društva ako će se statutom isključiti dispozitivan zakonski koncept ograničenja djelovanja uprave i nadzornog odbora ciljnog društva u ponudbenom razdoblju iz čl. 42. ZPDD-a de lege ferenda. Europsko pravilo proboja primijenit ce se, pak, prema Zakonu o izmjenama i dopunama ZPDD-a potpuno jednako kao i prema važećem ZPDD-u, odnosno samo ako se u statut ciljnog društva unese odredba koja sadrži pravila iz čl. 44. st. 2. Nacrta Zakona o izmjenama i dopunama ZPDD-a. 


\section{RAZLOZI ZA ZAOKRET GLEDE ČL. 42. ZPDD-A DE LEGE FERENDA U ODNOSU NA ČL. 42. ZPDD-A DE LEGE LATA}

Promjena položaja uprave i nadzornog odbora ciljnog društva u postupku preuzimanja je dakle ključna za razumijevanje izmjena i dopuna čl. 41., 42., 43., 44., 44.a te čl. 59. st. 1. t. 19., t. 16. i t. 20. ZPDD-a, sukladno Nacrtu Zakona o izmjenama i dopunama ZPDD-a. Prisilnopravni koncept neutralnosti uprave i nadzornog odbora ciljnog dioničkog društva uređen čl. 42. važećeg ZPDD-a zamjenjuje se novim dispozitivnim ublaženim konceptom neutralnosti koji u većoj mjeri uvažava ukupnost hrvatskoga pravnog sustava. Uvriježeni izraz neutralno držanje uprave i nadzornog odbora treba tumačiti sa zadrškom već de lege lata sa stajališta čl. 41. ZPDD-a. ${ }^{7}$ Uprava, a de lege ferenda i nadzorni odbor ciljnog društva, dužni su se jasno i nedvojbeno očitovati, pozicionirati o ponudi za preuzimanje te razotkriti svaki mogući sukob interesa u kojem se nalazi glede ponude za preuzimanje. Jasno je da u tom smislu nemaju prostora za uzmak, rezerviranost i hinjenje ravnodušnosti. Članovi uprave odgovorni su štoviše dioničarima već de lege lata za naknadu štete ako su znali, odnosno morali znati da mišljenje koje su dali nije točno, odnosno potpuno (čl. 41. st. 4. ZPDD-a). Neutralnost treba stoga shvatiti kao obvezu uprave i nadzornog odbora da u načelu ne poduzimaju radnje kojima bi se mogao onemogućiti uspjeh ponude za preuzimanje. De lege lata prisutan je očiti sukob između obveza uprave s naslova čl. 41. ZPDD-a i njenog ograničenog djelovanja sukladno čl. 42. ZPDD-a. Rješenje čl. 42. Nacrta Zakona o izmjenama i dopunama ZPDD-a de lege ferenda rješava taj trenutni normativni deficit tako što upravi daje prostor da djeluje ako je u okolnostima pojedinog slučaja interes društva važniji od interesa preuzimatelja i ekonomskog interesa dioničara ciljnog društva. Uprava to trenutno nije kadra učiniti, sve i da se meritorno izjasnila sukladno čl. 41. ZPDD-a o tomu da je konkretna ponuda za preuzimanje štetna za ciljno društvo. Takvo stanje nije održivo ni pravnopolitički opravdano tim više što je uprava dužna na temelju čl. 3. st. 1. t. 4. ZPDD-a postupati u najboljem interesu ciljnog društva. To jednostavno nije izvedivo pored jasne važeće kogentne odredbe čl. 42. ZPDD-a.

Na temelju čl. 42. ZPDD-a svako protuponuditeljsko djelovanje prebačeno je $\mathrm{s}$ uprave i nadzornog odbora u nadležnost glavne skupštine ciljnog društva. Praksa pokazuje da ciljna dionička društva nisu koristila mogućnost sazivanja glavne skupštine u ponudbenom razdoblju kako bi donosila protuponuditeljske mjere (v. čl. 42. st. 3. ZPDD-a). Korektiv europskog ograničenja djelovanja uprave i nadzornog odbora iz čl. 42. st 3. ZPDD-a, prebacivanje ovlaštenja protuponuditeljskog djelovanja s uprave na glavnu skupštinu ciljnog društva! - nije bio kadar otkloniti pravnopolitički razlog da se uprava i nadzorni odbor aktivnije uključe u postupak preuzimanja ako se za tim pokaže potreba sa stajališta interesa ciljnog društva i svih njegovih stakholdera. Rješenje čl. 42. ZPDD-a nije stoga pravnopolitički dobro uravnoteženo.

Nije sporno da uprava i nadzorni odbor ne smiju u načelu protuponuditeljski djelovati. U Nacrtu ZPDD-a je čak u odnosu na stanje de lege lata u čl. 59. dodana

7 Tako sa stajališta nama u tom dijelu poredbenoga njemačkog prava Hirte, H., op. cit. u bilj. 1, $\S 33$ rbr. 26. 
nova točka 20., kojom je prekršajnopravno sankcionirano protuponuditeljsko djelovanje članova uprave u ponudbenom razdoblju, osim ako takvo djelovanje nije bilo obuhvaćeno jednom od iznimaka iz čl. 42. st. 1. druga rečenica Nacrta Zakona o izmjenama i dopunama ZPDD-a. ${ }^{8}$ Poduzimanje svake protuponuditeljske mjere nailazi bez daljnjeg na opća ograničenja propisana Zakonom o trgovačkim društvima (Narodne novine, br. 111/93, 34/99, 121/99, 52/00, 118/03, 107/07, 146/08, 137/09, $111 / 12,125 / 11,68 / 13,110 / 15$; nadalje ZTD), posebice, na odredbe o odgovornosti uprave za naknadu štete društvu zbog propusta u vođenju poslova društva (čl. 252. ZTD-a). Zabranjene su, posebice, mjere kojima bi uprava razdijelila odnosno umanjila imovinu društva. U postupku preuzimanja nije, međutim, opravdano u potpunosti nekritički zatrti ovlaštenja uprave i nadzornog odbora propisana ZTD-om. Uprava i nadzorni odbor ne smiju se staviti po strani kako bi se otvorio put isključive zaštite usko ekonomskih interesa dioničara ciljnog društva. Prebacivanje protuponuditeljskog djelovanja s uprave na glavnu skupštinu ciljnog društva je u tom smislu tek puki normativni „smokvin list“ koji pokriva neopravdan pravnopolitički razlog da je uprava smrtni neprijatelj svakog preuzimanja i da su interesi društva izjednačeni u postupku preuzimanja sa živom trgovinom dionica ciljnog društva na burzi koja je redovito popraćena rastom vrijednosti dionica ciljnog društva.

Odredba čl. 42. st. 3. Nacrta ZPDD-a de lege ferenda omogućuje, također, hitno olakšano sazivanje glavne skupštine na kojoj bi se odlučivalo o protuponuditeljskom djelovanju. Članovi uprave kadri su se u tom smislu osloboditi odgovornosti za naknadu štete prema društvu sukladno čl. 252. st. 4. reč. 1. ZTD-a, ako su se njihove protuponuditeljske radnje temeljile na odluci glavne skupštine koja je bila sazvana sukladno čl. 42. st. 3. Nacrta ZPDD-a de lege ferenda. Odluke glavne skupštine o protuponuditeljskom djelovanju imaju i prema Nacrtu Zakona o izmjenama i dopunama ZPDD-a u tom smislu prednost pred protuponuditeljskim djelovanjem uprave ciljnog društva. Razlika je u tomu što će uprave ciljnih društava biti u većoj mjeri, nego što je to trenutno slučaj, motivirane da sazovu glavnu skupštinu sukladno čl. 42. st. 3. Nacrta Zakona o izmjenama i dopunama ZPDD-a, jer je to najpraktičniji način da izađu iz škripca u kojem će se najčešće naći. To je, s jedne strane, potencijalna odgovornost društvu s naslova čl. 252. ZTD-a ako stoje po strani dok su interesi društva narušeni neprijateljskom ponudom za preuzimanje, a s druge potencijalna prekršajna odgovornost s naslova čl. 59. st. 1. t. 20. Nacrta Zakona o izmjenama i dopunama ZPDD-a, ako se, a da za to nemaju opravdano uporište, započnu boriti protiv preuzimatelja.

Za očekivati je da odredba čl. 42. st. 2. Nacrta Zakona o izmjenama i dopunama ZPDD-a neće u većoj mjeri zaživjeti u praksi. Pričuvne odluke glavne skupštine dioničkog društva uređene čl. 42. st. 2. Nacrta Zakona o izmjenama i dopunama ZPDD-a omogućuju, doduše, upravi ciljnog društva učinkovito protuponuditeljsko djelovanje. Ne smije se, međutim, pritom zanemariti da takve pričuvne odluke glavne skupštine dioničkog društva signaliziraju tržištu kapitala da je konkretno ciljno društvo potencijalna meta preuzimanja. Pričuvne odluke glavne skupštine ne osiguravaju stoga dugotrajniju zaštitu budući da je ponuditelj koji se strateški

8 To je učinjeno po uzoru na pravilo iz $\S 60$ st. 1. t. 8 . njemačkoga WpÜG-a. 
opredijelio za preuzimanje kadar pravodobnim stjecanjem relevantnog paketa dionica spriječiti produljivanje već donesenih pričuvnih odluka glavne skupštine. ${ }^{9}$ Stjecanje relevantnog paketa dionica koji je kadar omogućiti ponuditelju da zaustavi donošenje pričuvnih odluka glavne skupštine, kao i ostalih protuponuditeljskih djelovanja glavne skupštine ciljnog društva, nije nikako za predanog preuzimatelja ključna prepreka u njegovom naumu da preuzme ciljno društvo i to ponajprije stoga što je zastupljenost dioničara na glavnim skupštinama u pravilu niska. ${ }^{10}$ Treba imati na umu i da je ponuditelj kadar pobijati odluke glavne skupštine kojima ciljno društvo protuponuditeljski djeluje pa tako i, tzv. pričuvne odluke glavne skupštine ciljnog društva. Za pretpostaviti je da uprava ciljnog društva neće posegnuti za ovlaštenjima koja joj je dala glavna skupština glede protuponuditeljskog djelovanja, osim ako su tužbe na pobijanje očito bez ikakvog izgleda na uspjeh. ${ }^{11}$ Uprava preuzima $u$ suprotnom na sebe sav rizik protuponuditeljskog djelovanja. Izlaže se odgovornosti za naknadu štete nastale društvu i vjerovnicima društva, na što će tim teže pristati uzme li se u obzir da će u slučaju uspješnog preuzimanja upravo preuzimatelj odlučivati o pokretanju odgovarajućih parnica protiv članova uprave koji su protuponuditeljski djelovali.

Glavna skupština ni sukladno čl. 42. ZPDD-a niti sukladno čl. 42. st. 2. i čl. 43. Nacrta Zakona o izmjenama i dopunama ZPDD-a nije, a niti ni neće u praksi znatno donositi protuponuditeljske odluke, iako je na to bila i ostala ovlaštena. To se samo u manjoj mjeri može argumentirati time da glavna skupština ciljnog društva u pravilu blagonaklono gleda na preuzimanje ili ga, štoviše, svojim neutralnim držanjem neizravno podržava. Jedina mogućnost iole važnijeg protuponuditeljskog djelovanja veže se stoga de lege ferenda uz radnje koje uprava poduzima uz prethodnu suglasnost nadzornog odbora kad to opravdavaju okolnosti pojedinog slučaja koje se mogu podvesti pod jednu od iznimaka iz čl. 42. Nacrta Zakona o izmjenama i dopunama ZPDD-a.

\section{KRITIKA ČL. 42. ZPDD-A DE LEGE LATA}

Odredba čl. 42. ZPDD-a slijedi odredbu čl. 9. Direktive 2004/25 EZ koja je sročena po uzoru na Rule 21.1. britanskoga City Code. Domaći zakonodavac nije obrazložio što ga je ponukalo da usvoji pravni režim propisan odredbom čl. 42. ZPDD-a. U nedostatku pravnopolitičkih ciljeva domaćeg zakonodavca, treba analizirati pravnopolitičke ciljeve koji su rukovodili europskog zakonodavca pri usvajanju čl. 9. Direktive 2004/25 EZ.

Grupa eksperata EU-a preporučila je kao temeljno načelo o kojem bi trebalo voditi računa u postupku preuzimanja dioničkih društava, to da su jedino i isključivo dioničari ciljnog društva ovlašteni odlučiti hoće li prihvatiti preuzimateljevu ponudu i pod kojim uvjetima. ${ }^{12}$ Preuzimatelju se po tom stajalištu mora kao imatelju kontrolnog

9 Tako Steinmeyer, op. cit. u bilj. 1, § 33 rbr. 54.

10 Tako Steinmeyer, op. cit. u bilj. 1, § 33 rbr. 54.

11 Tako Steinmeyer, op. cit. u bilj. 1, § 33 rbr. 54.

12 V. Report of the High Level Group of Company Law Experts on Issues Related to Takeover 
udjela u ciljnom društvu omogućiti odgovarajući utjecaj na vođenje poslova društva. ${ }^{13}$

Te se teze opravdavaju u pravilu konstatacijama da su preuzimanja apsolutno pozitivna pojava, jer služe tomu da stabiliziraju i preurede slabo pozicionirana i loše vođena društva, da preuzimanje dovodi do jačanja ciljnog društva putem sinergijskih učinaka povezivanja s preuzimateljem te da su uprava i nadzorni odbor ciljnog društva protivnici preuzimanja. ${ }^{14}$ Krajnje je, međutim, dvojbena teza da $\mathrm{s}$ ekonomskog stajališta neprijateljsko preuzimanje dovodi do premještanja produktivnih sredstava iz opadajućih gospodarskih sektora u one gospodarske sektore koji jamče veće prihode. ${ }^{15}$

Teze o blagotvornim ekonomskim učincima preuzimanja opravdano su izložene kritici i ne može ih se paušalno prihvaćati kao ocjenu realnog stanja, što ih ujedno diskvalificira da se neposredno koriste u vezi s prepoznavanjem i ocjenom pravnopolitičkih ciljeva ZPDD-a. ${ }^{16}$ Pritom se neopravdano ispušta iz vida da britansko pravo, koje je u tom smislu poslužilo kao pravo uzor, ne poznaje sankciju gubitka prava glasa prema ponuditelju koji krši svoje obveze propisane ZPDD-om, kao i to da britansko pravo počiva na drukčijem konceptu usporedi li ga se s pravima kontinentalnoeuropskog pravnog kruga kojem pripada hrvatsko pravo. Britanskom je pravu svakako interes dodatno jačati položaj Londona kao ključnog europskog financijskog sjedišta, a za što je liberalan pristup ponudama za preuzimanje bitan uvjet. Preuzimatelji i nadalje listaju svoje dionice na Londonskoj burzi, a ciljna društva će nakon provedenog preuzimanja u pravilu delistati svoje dionice s burze na kojoj su njihove dionice do tad kotirale. Zagrebačka burza spada, konkretno, među burze koje će zbog takva liberalnog pristupa preuzimanju dobiti kratkoročno življu, obimniju trgovinu, no dugoročno će trgovina dionicama ciljnih društava gotovo potpuno presahnuti budući da će u konačnici doći do njihova delistinga ili, pak, do istiskivanja manjinskih dioničara odnosno preoblikovanja ciljnog društva u društvo $\mathrm{s}$ ograničenom odgovornošću. ${ }^{17}$ Hrvatsko pravo tržišta kapitala gubi time na važnosti, na obujmu trgovine što svakako umanjuje njegovu relevantnost u odnosu na nama poredbena tržišta kapitala.

\subsection{Odredba čl. 42. ZPDD-a derogirala je nerazmjerno svom pravnopolitičkom cilju odredbu čl. 252. ZTD-a, a nije uvažila ni načela propisana čl. 3. st. 1. t. 3. i 4. ZPDD-a}

Čl. 3. st. 1. t. 3. ZPDD-a propisuje da su uprava i nadzorni odbor ciljnog društva dužni u razdoblju provedbe preuzimanja postupati u najboljem interesu ciljnog društva. Ponuditelj i ciljno društvo dužni su provesti postupak preuzimanja

Bids, Bruxelles, 2002. str. 2.

13 Report of the High Level Group of Company Law Experts on Issues Related to Takeover Bids, Bruxelles, 2002. str. 7.

14 V. o tim konstatacijama Parać, Z., op. cit. u bilj. 1, str. 38; Jurić, D., Zubović, A., op. cit. u bilj. 1 , str. 297.

15 O toj tezi v. Jurić, D., Zubović, A., op. cit. u bilj. 1, str. 297.

16 Tako Parać, Z., op. cit. u bilj. 1, str. 38.

17 V. istraživanje koje su o tom smislu provele Čulinović-Herc, E., Zubović, A., op. cit. u bilj. 1, str. 635, 636; Čulinović-Herc, E., Mikinac, O., op. cit. u bilj. 1, str. 92. 
što brže, a ciljno društvo ne smije duže vrijeme od predviđenog biti spriječeno $u$ svom poslovanju (čl. 3. st. 1. t. 4. ZPDD).$^{18}$ Odredba čl. 252. ZTD-a matično uređuje dužnu pažnju i odgovornost članova uprave dioničkog društva. Odredbe čl. 3. st. 1. t. 3. i 4. ZPDD-a podudaraju se u tom smislu s pravilima odredbe čl. 252. ZTD-a. Članovi uprave dioničkog društva moraju, naime, voditi poslove društva s pozornošću urednog i savjesnog gospodarstvenika i čuvati poslovnu tajnu društva. Članovi uprave dioničkog društva odgovaraju stoga ponajprije društvu za naknadu štete kao solidarni dužnici i to po načelu pretpostavljene krivnje. Članovi uprave kadri su se iznimno osloboditi te stroge odgovornosti za naknadu štete ako su pri donošenju poduzetničke odluke smjeli na temelju primjerenih informacija razumno pretpostaviti da djeluju za dobrobit društva (pravilo prosudbe razumnoga gospodarstvenika, čl. 252. st. 1. reč. 2. ZTD-a).

Stroga općenita zabrana upravi i nadzornom odboru da ometa ili onemogućuje uspjeh ponude za preuzimanje, propisana čl. 42. važećeg ZPDD-a, kosi se s prisilnopravnom odredbom čl. 252. ZTD-a. Odredba čl. 42. ZPDD-a kosi se štoviše i s općim načelima iz čl. 3. st. 1. t. 3. i 4. ZPDD-a.

Odredba čl. 42. ZPDD-a je u svakom slučaju lex specialis u odnosu na matičnu odredbu čl. 252. ZTD-a. Na odgovarajući način to se odnosi i na nadzorni odbor ciljnog društva pa je važeća odredba čl. 42. ZPDD-a, također, lex specialis i u odnosu na matičnu odredbu o dužnoj pozornosti i odgovornosti članova nadzornog odbora iz čl. 272. ZTD-a. Uprava ciljnog dioničkog društva nije stoga, u razdoblju nakon što je putem tržišnog operatera uređenog tržišta sukladno članku 4. ZPDD-a objavljena obavijest iz čl.9. st. 3. i čl. 10. st. 2. ZPDD-a pa do objave izvješća o preuzimanju, obvezna postupati u skladu sa strožim zahtjevima čl. 252. ZTD-a. Članovi nadzornog odbora i uprave su, naime, općenito oslobođeni svoje odgovornosti za naknadu štete za koju bi inače mogli odgovarati s naslova čl. 252. odnosno čl. 272. ZTD-a.

Treba ponajprije naglasiti da nikako nije sporno da su u ponudbenom razdoblju uprava i nadzorni odbor ograničeni u svom djelovanju. Posrijedi je prirodan standard, zahtjev prava društava kao odgovor na osobitosti postupka preuzimanja dioničkih društava koji zalazi u područje prava tržišta kapitala. Sporna je međutim mjera ograničenja uprave i nadzornog odbora u ponudbenom razdoblju. Treba li se, naime, uprava ciljnog društva bez iznimke držati neutralno u ponudbenom razdoblju i prepustiti eventualno protuponuditeljsko djelovanje glavnoj skupštini ciljnog društva, kao što je to slučaj s čl. 42. ZPDD-a, ili se treba proširiti krug iznimaka u kojima uprava nije ograničena u svom djelovanju tijekom ponudbenog razdoblja, kao što je to slučaj s čl. 42. Nacrta Zakona o izmjenama i dopunama ZPDD-a. Dobri razlozi govore u prilog drugoga koncepta. Pogrešno je, naime, upravi ciljnog društva beziznimno zabraniti da u postupcima preuzimanja poduzima radnje kojima bi mogla ugroziti

18 Treba naglasiti da $\S 3$ st. 3. i st. 4. reč. 2. njemačkoga WpÜG-a sadrže ista rješenja kao i čl. 3. st. 1. t. 3. i 4. ZPDD-a. WpÜG daje, međutim, sukladno spomenutim načelima pravo upravi i nadzornom odboru ciljnog društva širu mogućnost poduzimanja protuponuditeljskih mjera ako je to, naravno, u interesu ciljnog društva.

Jasno je stoga i s tog poredbenopravnog stajališta da rješenja iz čl. 3. i čl. 42. ZPDD-a nisu međusobno usklađena, ona se, naime, međusobno isključuju. Posrijedi je stoga dodatan bitan razlog za zakonodavnu intervenciju koja se zagovara u ovom radu. 
pravo dioničara da slobodno odluče o tomu hoće li prihvatiti ponudu za preuzimanje. ZPDD je nametnuo, međutim, upravi takvu pogrešnu kategoričnu obvezu neutralnosti u postupku preuzimanja u vezi s primjenom općih načela prava društava. Upravo tu zakonodavnu liniju razrađuje i preferira europski zakonodavac Direktivom 2004/25 EZ o ponudama za preuzimanje. Treba, međutim, ponovno naglasiti da europski zakonodavac nije pritom ni u kojem slučaju kategoričan te da je njemačko pravo za to najbolji primjer.

Na zaokret u uređenju čl. 42. ZPDD-a tjeraju ponajprije situacije u kojima interesi dobrobiti ciljnog društva nadilaze interese dioničara da od ponuditelja naplate što veću preuzimateljsku premiju. Praksa je pokazala da ni jedno dioničko društvo nije u svom statutu optiralo za europsko pravilo proboja iz čl. 43. ZPDD-a te da nije zabilježen ni jedan slučaj kad je u ponudbenom razdoblju glavna skupština ciljnog društva odlučivala o poduzimanju protuponuditeljskih mjera sukladno čl. 42. st. 2., 3 i 4. ZPDD-a. Potonja činjenica nije ponajprije rezultat favoriziranja postupka preuzimanja u domaćoj praksi, već je posljedica praktične neprovedivosti takvih protuponuditeljskih djelovanja de lege lata, a o čemu je već ranije u ovom tekstu bilo riječi.

\subsection{Odnos čl. 42. Nacrta Zakona o izmjenama i dopunama ZPDD i ZTD}

Članak 42. Nacrta Zakona o izmjenama i dopunama ZPDD-a nameće upravi ciljnog društva posebna pravila poslovnog ponašanja u postupku preuzimanja kad je ta ponuda za preuzimanje dana suprotno dobrobiti ciljnog društva (unfriendly, odnosno hostile takeover bid).${ }^{19}$ Pravila poslovnog ponašanja matično su uređena Zakonom o tržištu kapitala (Narodne novine, br. 88/2008, 146/2008, 74/2009, 54/2013, 159/2013, $18 / 2015,110 / 2015,123 / 2016,131 / 2017)$. Ona, njihova provedba, kao i kontrola njihove provedbe, ključni su za uspostavljanje povjerenja u uredno i neometano funkcioniranje tržišta kapitala. ${ }^{20}$ ZPDD propisuje posebna pravila poslovnog ponašanja uprave ciljnog dioničkog društva u postupku preuzimanja u odnosu na opća pravila o postupanju uprave koja su propisana odredbama čl. 240. i čl. 252. ZTD-a.

$\mathrm{Na}$ temelju čl. 42. Nacrta Zakona o izmjenama i dopunama ZPDD-a uprava ciljnog društva dužna se suzdržati od radnji koje bi mogle spriječiti uspjeh ponude za preuzimanje. Ta zabrana vrijedi samo u konkretnoj situaciji preuzimanja ciljnog društva. Izvan postupka preuzimanja, uprava se ravna pri poduzimanju protuponuditeljskih mjera isključivo po pravilima ZTD-a. Pravo društava ne nameće upravi nikakvo pravilo neutralnosti izvan postupka preuzimanja. Donese li uprava preventivno protuponuditeljske mjere koje će početi proizvoditi učinke pod odgodnim uvjetom da društvo zaista snađe neprijateljsko preuzimanje, te će mjere trebati izdržati test provjere sa stajališta čl. 42. prema Nacrtu Zakona o izmjenama i dopunama ZPDD-a. Nije sporno da je riječ o posebnom korporacijskopravnom standardu kojeg se uprava ciljnog društva dužna pridržavati u postupku preuzimanja. Rukovodi li

19 Tako sa stajališta čl. 42. Prijedloga ZPDD-a odgovarajućeg § 33 njemačkoga WpHG-a Steinmeyer, R., op. cit. u bilj. 1, § 33 rbr. 1, str. 658.

20 Više o pravilima poslovnog ponašanja Miladin, P., op. cit. u bilj. 1, str. 527 i nadalje. 
se uprava dominantno svojim vlastitim privatnim interesima, nastojeći sačuvati svoja stečena prava i osujetiti svoj izgledan opoziv, ona ne samo da se izvrgava odgovornosti za naknadu štete prema ciljnom društvu i vjerovnicima društva već se na temelju čl. 59. st. 1. toč. 20. Nacrta Zakona o izmjenama i dopunama ZPDD-a izlaže i prekršajnopravnoj odgovornosti.

U slučaju, tzv. neprijateljskog preuzimanja načelno pravilo po kojem uprava ne smije poduzimati protuponuditeljske mjere ne isključuje, međutim, prisilnoprave odredbe čl. 240. i 252. ZTD-a o materijalnopravnim i postupovnopravnim pretpostavkama poduzimanja protuponuditeljskih mjera. ${ }^{21}$ Posrijedi su ponajprije pravila ZTD-a o odgovornosti članova uprave za naknadu štete društvu i vjerovnicima društva te pravila ZTD-a o pretpostavkama za poduzimanje određenih radnji. Njih su se članovi uprave dužni držati kane li poduzimati protuponuditeljske mjere.

\subsection{Protuponuditeljsko djelovanje uprave ciljnog društva de lege ferenda}

\subsubsection{Pregled}

Novi koncept sprječavanja ponude za preuzimanje nikako ne znači da su ovlasti za poduzimanje protuponuditeljskih mjera prebačene $\mathrm{s}$ uprave na glavnu skupštinu, kao što to inače vrijedi za europsku zabranu sprječavanja ponude za preuzimanje te za čl. 42. ZPDD-a. Europsko ograničenje djelovanja uprave i nadzornog odbora ciljnog društva, koje je uređeno čl. 43. Nacrta Zakona o izmjenama i dopunama ZPDD-a zapravo je odredba kojom se kompetencije poduzimanja protuponuditeljskih mjera prebacuju s uprave na glavnu skupštinu ciljnog društva, a što je u konačnici praktički neprovedivo u domaćoj korporativnoj praksi. Prema Nacrtu Zakona o izmjenama i dopunama ZPDD-a odredba čl. 42. ZPDD-a ostaje, također, i u postupku preuzimanja u okviru važećeg pravila o tomu da su uprava i nadzorni odbor ciljnog društva dužni djelovati neutralno, no nastoji se istodobno u najvećoj mogućoj mjeri uravnotežiti to pravilo s općim standardima prava društava, odnosno ZTD-a u dijelu koji se tiče odgovornosti i ovlaštenja uprave i nadzornog odbora dioničkog društva.

Glavnu skupštinu treba stoga prisilnopravno uključiti u poduzimanje protuponuditeljskih mjera samo ako je inače ZTD-om propisano da je za stupanje na snagu ili donošenje određenih odluka potrebna i suglasnost glavne skupštine dioničkog društva. Uprava smije, također, koristiti ovlaštenja koja joj je dala glavna skupština na temelju općih pravila prava društava, samo ako su se za to ispunile pretpostavke propisane čl. 42. st. 1. reč. 2., prema Nacrtu Zakona o izmjenama i dopunama ZPDD-a. Odredba čl. 42. st. 1. reč. 2. ZPDD-a Nacrta Zakona o izmjenama i dopunama ZPDD-a ne uključuje, pak, protuponuditeljske mjere koje su donesene na temelju ad hoc odluka glavne skupštine ni na pričuvne, rezervne protuponuditeljske mjere koje je glavna skupština donijela na temelju čl. 42. st. 2. Nacrta Zakona o izmjenama i dopunama ZPDD-a.

21 Tako sa stajališta čl. 42. Prijedloga ZPDD-a odgovarajućeg § 33 njemačkoga WpHG-a Steinmeyer, R., op. cit. u bilj. 1, § 33 rbr. 6, str. 660. 


\subsubsection{Područje primjene}

Odredba se primjenjuje samo na radnje uprave koje ona poduzme u postupku preuzimanja odnosno u razdoblju nakon što je putem tržišnog operatera uređenog tržišta objavljena odluka o davanju javne ponude za preuzimanje pa do objave izvješća o preuzimanju. Nije pritom bitno je li uprava znala za ponudu za preuzimanje. Odredba čl. 42. ZPDD-a prema Nacrtu Zakona o izmjenama i dopunama ZPDD-a odnosi se samo na one protuponuditeljske mjere koje se poduzimaju kao reakcija na ponudu za preuzimanje (represivne protuponuditeljske mjere, ad hoc protuponuditeljske mjere). Odredbom nisu stoga obuhvaćene protuponuditeljske mjere koje se poduzimaju preventivno, neovisno o nekoj konkretnoj ponudi za preuzimanje (preventivne protuponuditeljske mjere). ${ }^{22}$ Pravna sigurnost nalaže da se tako postupa, također, i kad su se već i prije nego što je sukladno čl. 4. ZPDD-a objavljena odluka o davanju javne ponude za preuzimanje počele širiti glasine o predstojećem preuzimanju. ${ }^{23}$

Odredba se primjenjuje samo na javne ponude za preuzimanje koje su usmjerene na ostvarivanje kontrole nad ciljnim društvom. Nova odredba čl. 42. ZPDD-a prema Nacrtu Zakona o izmjenama i dopunama ZPDD-a ne odnosi se na, tzv. običnu javnu ponudu za stjecanje dionica ciljnog društva. Ona se, također, ne primjenjuje ni kad ponuditelj u trenutku kad je objavio odluku o davanju javne ponude još nije precizirao je li riječ o odluci da dade javnu ponudu za preuzimanje ili, tzv. običnu javnu ponudu za stjecanje dionica ciljnog društva. ${ }^{24}$

Odredba čl. 42. ZPDD-a prema Nacrtu Zakona o izmjenama i dopunama ZPDD-a primjenjuje se na odgovarajući način i na obvezne ponude za preuzimanje. ${ }^{25} \mathrm{U}$ praksi neće biti važnijeg upućivanja na primjenu odredbe čl. 42. prema Nacrtu Zakona o izmjenama i dopunama ZPDD-a i kod obveznih ponuda za preuzimanje jer će uprava ciljnog društva jedva i moći poduzimati protuponuditeljske mjere protiv ponuditelja koji je već ostvario kontrolu u društvu. Tamo gdje bi to iznimno bio slučaj, moguća je smislena primjena odredbe čl. 42. prema Nacrtu Zakona o izmjenama i dopunama ZPDD-a, posebice, mogućnost korištenja pričuvnih odluka glavne skupštine ciljnog društva sukladno čl. 42. st. 2. prema Nacrtu Zakona o izmjenama i dopunama ZPDD-a.

Nadzorni odbor ciljnog društva nije podvrgnut primjeni čl. 42. Nacrta Zakona o izmjenama i dopunama ZPDD-a glede svojih kontrolnih ovlasti, kao ni u okviru svojih ovlasti propisanih čl. 42. st. 1. reč. 2., 3. alternativa prema Nacrtu Zakona o izmjenama i dopunama ZPDD-a. Poduzme li, pak, nadzorni odbor iznimno radnje na

22 Steinmeyer, R., op. cit., u bilj. 1, § 33 rbr. 10.

23 Steinmeyer, R., op. cit., u bilj. 1, § 33 rbr. 10.

24 Steinmeyer, R., op. cit., u bilj. 1, § 33 rbr. 10. Ponuda za preuzimanje razlikuje se od obične javne ponude za stjecanje dionica ciljnog društva. Obična javna ponuda za preuzimanje dionica uvijek je kontrolno neutralna i razlikuje se od ponude za preuzimanje upravo po tomu što nije usmjerena na ostvarivanje kontrole u ciljnom društvu. Riječ je faktično o dvije situacije. U prvom slučaju riječ je o, tzv. ulaznoj ponudi; kad ponuditelj daje ponudu za stjecanje dionica ispod kontrolnog praga s tim da ponuditelj ne doseže kontrolni prag kad se zbroje dionice koje on već ima i iz kojih mu se pribrajaju prava glasa te dionice koje će tek steći javnom ponudom za stjecanje dionica. U drugom slučaju riječ je o javnoj ponudi za stjecanje dionica kad je ponuditelj već premašio kontrolni prag i odlučio je dati ponudu za dodatno stjecanje dionica.

25 Tako i § 39 njemačkog WpÜG-a. 
temelju čl. 244., 247., 263. st. 2., 268. ZTD-a kojima je kadar neizravno utjecati na ovlasti uprave da vodi poslove društva, čl. 42. prema Nacrtu Zakona o izmjenama i dopunama ZPDD-a primijenit će se na odgovarajući način. Odredba se ne primjenjuje na organe povezanih društava. Oni su dužni samo općenito svesti svoje interese u granice pravne zaštite. Uprava vladajućeg ciljnog društva dužna je, međutim, poduzeti prikladne mjere da se uzduž čitavog koncerna sva ovisna društva suzdrže od radnji kojima se otežava ili sprječava uspjeh ponude za preuzimanje. Glavna skupština ciljnog društva nije podvrgnuta zabrani sprječavanja ili otežavanja uspjeha ponude za preuzimanje. Glavna skupština ovlaštena je donositi protuponuditeljske mjere isključivo uz ograničenja propisana ZTD-om i ona nije u tom smislu ograničena ZPDD-om. Sazivanje i održavanje glavne skupštine je u tom smislu olakšano i de lege ferenda na temelju odredbe čl. 42. st. 3. Nacrta Zakona o izmjenama i dopunama ZPDD-a.

U nastavku se detaljnije obrazlažu dvije ključne novine čl. 42. ZPDD-a sukladno Nacrtu Zakona o izmjenama i dopunama ZPDD-a.

4.3.2.1. Radnje uprave ciljnog društva koje bi, također, poduzeli pozornošću urednog $i$ savjesnog gospodarstvenika i članovi uprave nekog društva glede kojeg nije dana ponuda za preuzimanje (čl. 42. st. 1. rečenica 2., prva alternativa Nacrta Zakona o izmjenama i dopunama ZPDD-a)

Nacrt Zakona o izmjenama i dopunama ZPDD-a jasnim upućivanjem na izričaj čl. 252. st. 1. ZTD-a dopušta upravi ciljnog društva da poduzima i one radnje koje bi se poduzimale da nije bila dana ponuda za preuzimanje. Ova iznimka od načela neutralnosti nameće se već i de lege lata budući da bi inače gotovo svaka radnja uprave ciljnog društva bila kadra spriječiti uspjeh ponude za preuzimanje.

Interes što je moguće manjeg ometanja redovnog poslovanja ciljnog društva nameće potrebu da se nastavi sa svakodnevnim, operativnim redovitim poslovanjem ciljnog društva, kao i to da ciljno društvo nastavi ispunjavati ugovorne i druge pravne obveze koje je preuzelo prije nego što je bila objavljena odluka o davanju ponude za preuzimanje.

Pitanje je smije li uprava ciljnog društva na ovoj osnovi poduzimati također i izvanredne poslove. Treba stoga izričito naglasiti da uprava ciljnog društva smije po ovoj osnovi nastaviti s provedbom zacrtanih i ranije usvojenih poslovnih strategija. ${ }^{26}$ Pitanje je i kako se uprava ciljnog društva treba konkretno pozvati na provedbu poslovne strategije pri donošenju svoje odluke u postupku preuzimanja te koji se dokazi trebaju u tom smislu zahtijevati od uprave ciljnog društva. ${ }^{27}$ Svakako bi se trebalo ustrajati na poslovnoj strategiji koja nije starija od godinu dana te bi bilo poželjno da su se dioničari mogli o njoj izjasniti na glavnoj skupštini ciljnog društva. Poslovna strategija mora biti javno objavljena i to prije nego što je započeo postupak preuzimanja u kojem je uprava u pravilu u sukobu interesa. Ona može ponajprije biti sadržana u financijskim izvješćima ciljnog društva, no nema zapreke da se na neki

26 Tako Obrazloženje njemačke Vlade u povodu predlaganja WpÜG, RegE BT-Drucks. 14/7034, str. 58.

27 Steinmeyer, R., op. cit., u bilj. 1, § 33 rbr. 20. 
drugi način javno iskomunicirala, primjerice, putem konferencije za medije, prema analitičarima i potencijalnim ulagateljima ili slično. Upravi se tim pravilom nameće dodatni standard odgovornosti glede urednog dokumentiranja zacrtane i usvojene poslovne strategije budući da uprava snosi teret dokaza da su u pojedinom slučaju ispunjene pretpostavke iznimki od pravila neutralnosti propisanog spomenutim pravilom.

Uprava ciljnog društva smije poduzimati izvanredne poslove ako je odluku o njihovu poduzimanju donijela ili ako ih je započela poduzimati prije nego što je započeo postupak preuzimanja.

Oslanjanje na usvojenu poslovnu strategiju otvara brojne mogućnosti protuponuditeljskog djelovanja. Riječ je, primjerice, o preuzimanju određenog ciljnog društva koje preuzimatelja izlaže brojnim teškim kartelnopravnim rizicima ili, pak, o otuđenju određenih pogona ciljnog društva koji su preuzimatelju izrazito atraktivni. ${ }^{28}$

Pod ovim pravilom ne misli se na to da je uprava ciljnog društva ovlaštena poduzimati sve one radnje koje bi bila kadra poduzimati neovisno o postupku preuzimanja koji je zadesilo ciljno društvo. Uprava ciljnog društva ne smije, naime, u postupku preuzimanja poduzimati radnje kojima mijenja zacrtanu i usvojenu poslovnu strategiju. Ona je njome vezana i u postupku preuzimanja. Zauzme li se, naime, suprotno stajalište, izostala bi potreba za primjenom čl. 42. st. 1. rečenica 2., druga i treća alternativa Nacrta Zakona o izmjenama i dopunama ZPDD-a.

\subsubsection{Radnje uprave uz prethodnu suglasnost nadzornog odbora (čl. 42. st. 1. rečenica 2., tré́a alternativa $Z P D D$-a de lege ferenda)}

Posezanje za protuponuditeljskim mjerama ne mora nužno ovisiti o tomu bi li uredni i pošteni član uprave smio poduzeti konkretne radnje neovisno o postupku preuzimanja. Posrijedi su stoga mjere koje se smiju poduzimati upravo u slučajevima preuzimanja ciljnog društva i to kao izravni odgovor u povodu neke konkretne ponude za preuzimanje. To objašnjava veliku potencijalnu praktičnu važnost ove iznimke od pravila da su uprava i nadzorni odbor ciljnog društva u načelu neutralni u postupku preuzimanja. Uprava smije uz prethodnu suglasnost nadzornog odbora poduzimati radnje koje ne spadaju u redovito, svakodnevno poslovanje ciljnog društva ili se kreću izvan zacrtanog poslovnog plana odnosno utvrđene strategije društva. Kao odgovor na ponudu za preuzimanje smije se, štoviše, promijeniti utvrđena strategija društva. Sa stajališta ZPDD-a sva se posebnost odlučivanja uprave u postupku preuzimanja svodi na to da uprava u pravilu ne smije samostalno poduzimati protuponuditeljske mjere, iako bi ih ona inače po općem pravnom režimu prava društava bila ovlaštena poduzimati samostalno, već je za njihovo poduzimanje dužna pribaviti suglasnost nadzornog odbora. Druga je posebnost, da uprava smije koristiti ovlaštenja koja joj je na temelju ZTD-a dala glavna skupština za poduzimanje protuponuditeljskih mjera, samo ako su se za to ispunile pretpostavke propisane novim čl. 42. st. 1. reč. 2. ZPDD-a prema Nacrtu Zakona o izmjenama i dopunama ZPDD-a. Uprava ciljnog društva smije po općim pravilima prava društava uz prethodnu suglasnost nadzornog

28 Steinmeyer, R., op. cit., u bilj. 1, § 33 rbr. 22. 
odbora posegnuti i za ovlaštenjima koja joj je dala glavna skupština, no samo ako to ovlaštenje predviđa protuponuditeljsko djelovanje, barem na općenitoj, apstraktnoj razini. Prethodna suglasnost nadzornog odbora nije stoga kadra osnažiti poslove za koje je uprava ciljnog društva bila dužna ishoditi suglasnost glavne skupštine.

Nadzorni odbor nije ništa manje odgovoran od uprave pri odlučivanju o tomu hoće li dati ili uskratiti suglasnost upravi za poduzimanje protuponuditeljskih radnji. Članak 3. st. 1. toč. 3. ZPDD-a jasno propisuje da su uprava i nadzorni odbor ciljnog društva dužni u razdoblju provedbe postupka preuzimanja postupati u najboljem interesu ciljnog društva. Odredba čl. 272. ZTD-a o dužnoj pozornosti i odgovornosti članova nadzornog odbora upućuje na primjenu odredbe čl. 252. ZTD-a o dužnoj pozornosti i odgovornosti članova uprave. Jasno je stoga da su oba organa dužna u jednakoj mjeri štititi interese ciljnog društva. Ratio legis nije stoga da se glavna skupština zaobiđe pri odlučivanju o protuponuditeljskom djelovanju ni da se nadzornom odboru dadu tobožnja ovlaštenja da po svom potpuno slobodnom nahođenju paušalno osnažuje ma koje protuponuditeljsko djelovanje uprave ciljnog društva.

U praksi se očekuje od uprave ciljnog društva da svoje dvojbe, ako je to naravno ikako moguće, oko primjene čl. 42. st. 1. reč. 2. prva, odnosno treća alternativa ZPDD-a sukladno Zakonu o izmjenama i dopunama ZPDD-a, razriješi tako da konkretne protuponuditeljske mjere poduzima u pravilu isključivo uz prethodnu suglasnost nadzornog odbora. Članovi uprave ciljnog društva kadri su se tako zaštititi od mogućih sankcija. U slučaju dodatne dvojbe preporučuje se ishoditi i dodatnu suglasnost glavne skupštine ciljnog društva sukladno čl. 275. st. 2. ZTD-a.

Posezanje za protuponuditeljskim mjerama ne narušava obveze propisane čl. 42. st. 1. ZPDD-a ako pri odmjeravanju međusobno suprotstavljenih interesa uprava ciljnog društva smije razumno pretpostaviti da prednost treba dati interesima ciljnog društva i njegovih dionika, stakholdera naspram interesa dioničara ciljnog društva. Članovi uprave ciljnog društva nisu u suprotnom kadri otkloniti predmnijevu po kojoj su se u svom protuponuditeljskom djelovanju rukovodili, u odlučujućoj mjeri između ostalog, i svojim vlastitim interesima.

\section{ZAKLJUČAK}

Nije sporno da uprava ciljnog dioničkog društva ima pravo i obvezu voditi poslove ciljnog društva, a nije sporno ni to da se ona u razdoblju preuzimanja svog društva treba suzdržati od svih radnji kojima bi bila kadra osujetiti uspjeh istaknute ponude za preuzimanje svog ciljnog društva. Dvojbeno je, međutim, je li pravnopolitički opravdano radikalno odustati od uvriježenog standarda prava društava po kojem uprava odgovara za vođenje poslova društva u postupku preuzimanja ciljnog dioničkog društva. Odredba čl. 42. ZPDD-a, dakle postojeće pravno uređenje položaja uprave ciljnog društva u postupku preuzimanja, neprimjereno odstupa već od proklamiranih načela ZPDD-a, po kojima je uprava ciljnog društva dužna u razdoblju preuzimanja postupati u najboljem interesu ciljnog društva, a ciljno društvo ne smije duže vrijeme od predviđenog biti spriječeno u svom poslovanju (čl. 3. st. 1. t. 3. i 4. ZPDD-a). Odstupanje čl. 42. ZPDD-a od općeg prisilnopravnog režima iz 
čl. 252. ZTD-a pravnopolitički je opravdano, no treba ga svesti, sukladno rješenjima predloženim u ovom radu u granice zacrtane ustavnopravnim načelima primjerenosti i razmjernosti, odnosno odmjeravanja međusobno suprotstavljenih interesa. Uprava ciljnog društva treba uvijek poći od toga da postupak preuzimanja nije alibi za to da se ona bezuvjetno oslobodi svoje odgovornosti za vođenje poslova društva s naslova čl. 252. ZTD-a. U okolnostima svakoga pojedinog slučaja preuzimanja ciljnog društva, uprava treba odvagati pretežu li interesi dioničara da što bolje unovče svoje dionice ili, pak, interesi dobrobiti ciljnog društva. Članovi uprave ciljnog društva nalaze se u postupku preuzimanja u iznimno osjetljivom položaju jer, s jedne strane, odgovaraju za naknadu štete društvu i vjerovnicima društva s naslova čl. 252. ZTD-a, a s druge odgovaraju ne samo za naknadu štete već i prekršajnopravno ometaju li ponudu za preuzimanje (v. čl. 59. st. 1. t. 20. ZPDD-a sukladno Nacrtu Zakona o izmjenama i dopunama ZPDD-a), a da za to nemaju uporište u zakonom propisanim iznimkama. Rad zagovara Nacrt Zakona o izmjenama i dopunama članaka 41., 42., 43., 44., 44.a te članka 59. stavak 1. točka 19., točka 16. i točka 20. ZPDD-a, a koji je uz njega priložen. Spomenuti tekst sročen je po uzoru na njemački WpÜG. Tom se prijedlogu ne protivi Direktiva 2004/25 EU, budući da ona počiva u dijelu koji uređuje položaj uprave ciljnog društva u postupku preuzimanja na opcijskom modelu te je predloženi zakonodavni zaokret u tom smislu prihvatljiv sa stajališta usklađenosti s europskim pravom.

Prilog 1. Tekst Nacrta Zakona o izmjenama i dopunama članaka 41., 42., 43., 44., 44.a te članka 59. stavak 1. točka 19., točka 16. i točka 20. ZPDD-a

U članku 41. mijenja se naslov iznad njega koji glasi:

„Mišljenje uprave i nadzornog odbora ciljnog društva“"

U stavku (1) u prvoj rečenici prije dvotočke iza riječi „uprava“ dodaju se riječi „,i nadzorni odbor". Stavak (1) točka 4. mijenja se i glasi:

„Izjave članova uprave i nadzornog odbora o njihovoj namjeri da ponudu za preuzimanje prihvate ili odbiju, ako su ujedno i dioničari ciljnog društva,"“

U stavku (1) točka 5. iza riječi ,,uprave“ dodaju se riječi ,i nadzornog odbora“.

U stavku (2) iza riječi ,uprava“ dodaju se riječi „, nadzorni odbor“.

U stavku (3) iza riječi „uprava“ dodaju se riječi ,i nadzorni odbor“, a riječi „obvezna je“ zamjenjuju se riječima „obvezni su“.

U stavku (5) iza riječi „,uprava“ dodaju se riječi „, nadzorni odbor“, a riječi „obvezna je“ zamjenjuju se riječima „obvezni su“.

U stavku (6) u prvoj rečenici iza riječi „uprave“ dodaju se riječi „ili nadzornog odbora“. U stavku (6) briše se druga rečenica.

Članak 42. mijenja se i glasi:

„Djelovanja uprave ciljnog društva

„(1)Uprava ciljnog društva ne smije poduzimati radnje kojima bi bila kadra onemogućiti uspjeh ponude za preuzimanje u razdoblju nakon što je putem tržišnog operatera uređenog tržišta sukladno članku 4. ovog Zakona objavljena obavijest iz članka 9. 
stavka 3. i članka 10. stavka 2. ovog Zakona pa do objave izvješća o preuzimanju. To se ne odnosi na radnje uprave ciljnog društva koje bi, također, poduzeli pozornošću urednog i savjesnog gospodarstvenika i članovi uprave nekog društva glede kojeg nije dana ponuda za preuzimanje, na potragu za drugim konkurentskim ponuditeljima za preuzimanje ni na radnje uprave ciljnog društva s kojima se suglasio nadzorni odbor ciljnog društva.

(2) Ovlasti li glavna skupština upravu prije razdoblja iz stavka 1. ovoga članka na poduzimanje radnji, koje spadaju u nadležnost glavne skupštine, kako bi se spriječio uspjeh ponude za preuzimanje te se radnje trebaju odrediti odlukom glavne skupštine prema vrsti ovlaštenja koju je glavna skupština prenijela na upravu. Ovlaštenje se daje na najdulje 18 mjeseci. Glavna skupština donosi odluku o tome većinom od najmanje tri četvrtine temeljnog kapitala zastupljenog na toj glavnoj skupštini; statutom se može propisati da je za to potrebna veća većina, a može se zahtijevati i ispunjenje dodatnih pretpostavki. Nadzorni odbor treba se suglasiti s radnjama uprave iz rečenice 1. ovog stavka.

(3) Odredbe čl. 43. st. 5., 6., i 7. ovog Zakona primjenjuju se na odgovarajući način ako se $u$ vezi s ponudom za preuzimanje sazove glavna skupština ciljnog društva, $u$ razdoblju nakon što je putem tržišnog operatera uređenog tržišta sukladno članku 4. ovog Zakona objavljena obavijest iz članka 9. stavka 3. i članka 10. stavka 2. ovog Zakona pa do objave izvješća o preuzimanju

(4) Ponuditelj i osobe koje s njim zajednički djeluju ne smiju davati ni nuditi članovima uprave i nadzornog odbora ciljnog društva nedopuštenu novčanu činidbu ni bilo kakvu drugu nedopuštenu imovinsku korist kako bi time zadobili njihovo savezništvo u postupku preuzimanja ciljnog društva.“.

Članak 43. mijenja se i glasi:

„Europska ograničenja djelovanja uprave i nadzornog odbora ciljnog društva

1. Statutom ciljnog društva može se isključiti primjena članka 42. ovog Zakona. U tom slučaju primjenjuju se odredbe stavka 2. ovog članka.

2. Uprava i nadzorni odbor ciljnog društva ne smiju, bez odobrenja glavne skupštine ciljnog društva, u razdoblju nakon što je putem tržišnog operatera uređenog tržišta sukladno članku 4. ovog Zakona objavljena obavijest iz članka 9. stavka 3. i članka 10. stavka 2. ovog Zakona pa do objave izvješća o preuzimanju:

a. povećati temeljni kapital,

b. sklapati poslove izvan redovitog poslovanja društva,

c. djelovati na način koji bi mogao ozbiljnije ugroziti daljnje poslovanje ciljnog društva ili sklapati poslove koji bi mogli ozbiljnije ugroziti daljnje poslovanje ciljnog društva,

d. odlučiti o stjecanju ili otuđivanju vlastitih dionica ciljnog društva ili vrijednosnih papira koji daju pravo glasa,

e. djelovati na drugi način koji bi imao za cilj ometanje ili onemogućavanje ponude za preuzimanje. 
3. Odluke uprave i nadzornog odbora iz stavka 2. ovog članka koje su donesene prije dana objave obavijesti iz članka 9. stavka 3. i članka 10. stavka 2. ovoga Zakona, a nisu u cijelosti provedene, moraju prije provedbe dobiti dodatno odobrenje glavne skupštine ciljnog društva, osim ako se radi o odlukama koje spadaju u redovito poslovanje ciljnog društva, a njihova provedba ne bi mogla ometati ili onemogućiti ponudu za preuzimanje. Ništetne su sve odluke uprave i nadzornog odbora ciljnog društva donesene u suprotnosti s odredbama ovog i prethodnog stavka ovog članka.

4. Uprava ciljnog društva obvezna je, bez odgode, obavijestiti Agenciju i nadzorna tijela država članice europskog ekonomskog prostora u kojima se trguje dionicama ciljnog društva na organiziranom tržištu, o tome da je ciljno društvo usvojilo ili brisalo odredbu statuta prema stavku 1. ovog članka.

5. Neovisno o rokovima za sazivanje glavne skupštine ciljnog društva propisanim Zakonom o trgovačkim društvima, glavna skupština ciljnog društva na kojoj će se odlučivati o djelovanjima iz stavka 2. točka 1 . ovog članka, može se sazvati najkasnije 14 dana prije dana održavanja glavne skupštine.

6. Kod sazivanja održavanja glavne skupštine na kojoj će se odlučivati o djelovanjima iz stavka 2. točka 1. ovoga članka, ciljno društvo može slobodno izabrati mjesto održavanja glavne skupštine i pritom nije dužno postupiti u skladu s odredbom članka 277. stavka 4. Zakona o trgovačkim društvima i eventualnim drukčijim odredbama statuta. Ako je rok za sazivanje glavne skupštine kraći od roka iz članka 279. stavka 1. Zakona o trgovačkim društvima, rok za pohranu dionica i prijavu sudjelovanja sukladno članku 279. Zakona o trgovačkim društvima je 4 dana. Društvo treba olakšati dioničarima izdavanje punomoći za glasovanje, ako je to moguće prema zakonu i statutu. Priopćenja dioničarima, izvješće prema članku 308. stavku 5. drugoj rečenici Zakona o trgovačkim društvima i pravodobno predani prijedlozi dioničara moraju biti dostupni i u skraćenom obliku objavljeni svim dioničarima. Priopćenja se ne moraju slati ako uprava, uz suglasnost nadzornog odbora, smatra da nije vjerojatno da će pravodobno biti dostavljena dioničarima. Kod prijedloga o kojima se glasuje, odredba članka 284. stavka 2. druge rečenice Zakona o trgovačkim društvima primjenjuje se u ovom slučaju i na dionice na donositelja.

7. Odluka glavne skupštine o djelovanjima iz stavaka 2. i 3. ovog članka donose se glasovima koji predstavljaju najmanje tri četvrtine temeljnog kapitala zastupljenog na glavnoj skupštini pri odlučivanju o djelovanjima iz stavka 2. točka 1 . ovog članka.

8. Traženje drugih ponuditelja nije djelovanje iz stavka 2. ovoga članka.

9. Ograničenja iz ovog članka ne primjenjuju se ako ponuditelj i osobe koje djeluju zajednički ne provedu postupak preuzimanja u zakonski predviđenim rokovima. U smislu ove odredbe, neće se smatrati da ponuditelj i osobe koje zajednički djeluju ne provode postupak preuzimanja u zakonski predviđenim rokovima ako je, s obzirom na okolnosti slučaja, riječ o kratkotrajnom prekoračenju roka.“

U članku 44. dodaje se naslov koji glasi: 


\section{„Pravilo proboja“}

U članku 44. iza stavka 6. dodaju se novi stavci 7. i 8. koji glase:

7. Uprava ciljnog društva obvezna je, bez odgode, obavijestiti Agenciju i nadzorna tijela država članica europskog ekonomskog prostora u kojima su uvrštene dionice ciljnog društva na uređenom tržištu, o tome da je ciljno društvo usvojilo ili brisalo odredbu statuta prema stavku 1. ovog članka.

8. Na sazivanje i vođenje glavne skupštine iz članka 44. stavka 4. ovoga Zakona, na odgovarajući način se primjenjuju odredbe članka 43. stavka 4., 5., i 6. ovoga Zakona.“

Iza članka 44. dodaje se novi članak 44.a koji glasi:

'Načelo uzajamnosti

1. Ako statut ciljnog društva isključuje primjenu članka 42. ovoga Zakona glavna skupština ciljnog društva može odlučiti da će se članak 42. ovoga Zakona ipak primijeniti ako ponuditelj ili njegovo vladajuće društvo nisu podvrgnuti primjeni pravila koja odgovaraju onima iz članka 43. ovog Zakona.

2. Ako statut ciljnog društva sadrži odredbu iz članka 44. ovoga Zakona glavna skupština ciljnog društva može odlučiti da se ta odredba statuta ipak neće primijeniti ako ponuditelj ili njegovo vladajuće društvo nisu podvrgnuti primjeni pravila koja odgovaraju onima iz članka 44. ovog Zakona.

3. Na temelju odgovarajuće odluke svoje glavne skupštine ciljno društvo može pridržati pravo primjene načela uzajamnosti sukladno stavcima 1. i 2. ovog članka. Odluka glavne skupštine vrijedi najdulje 18 mjeseci. Uprava ciljnog društva obvezna je, bez odgode, obavijestiti Agenciju i nadzorna tijela država članica europskog ekonomskog prostora u kojima su uvrštene dionice ciljnog društva na uređenom tržištu o tome da ju je glavna skupština ovlastila primjenjivati načelo uzajamnosti. Uprava je obvezna objaviti na web stranici ciljnog društva to svoje ovlaštenje.“

U članku 59. u stavku 1. točka 19. iza riječi ,javnošću“ briše se „. . “i umjesto nje dodaje ", “

U članku 59. u stavku 1. mijenja se točka 16. koja glasi:

„16. protivno odredbama članka 43. stavka 4., članka 44. stavka 7. ili članka 44.a stavka 3. rečenica 3. ovoga Zakona, uopće ne obavijesti, netočno, nepotpuno ili nepravovremeno obavijesti Agenciju i nadzorna tijela država članica europskog ekonomskog prostora u kojima su uvrštene dionice ciljnog društva u uređenom tržištu,"

U članku 59. u stavku 1. dodaje se nova točka 20. koja glasi: 
„20. protivno odredbama članka 42. stavka 1. rečenica 1. ili članka 43. stavka 2. i 3. ovoga Zakona, poduzme radnje."

\section{LITERATURA}

\section{Pravni izvori}

1. Britanski City Code on Takeovers and Mergers, 1968, jedanaesta revizija 19. rujna 2011.

2. Direktiva 2004/25 Europske zajednice od 21. travnja 2004. o ponudama za preuzimanje

3. Obrazloženje njemačke Vlade povodom predlaganja Wertpapiererwerbs- und Übernahmegesetz, Regierungsentwurf Bundestag-Drucks. 14/7034.

4. Odluka Ustavnog suda Republike Hrvatske broj: U-I-977/2004 od 22. studenog 2006.

5. Odluka Ustavnog suda Republike Hrvatske broj: U-I-4468/2008 od 8. srpnja 2013.

6. Odluka Ustavnog suda Republike Hrvatske broj: U-I-2479/2100 od 9. srpnja 2013.

7. Odluka ministra financija dr. sc. Zdravka Marića o osnivanju Radne skupine za izradu nacrta Prijedloga Zakona o preuzimanju dioničkih društava klasa: 011-01/16-01/22 urbroj: 513-06-03-16-2 od 5. svibnja 2016.

8. Report of the High Level Group of Company Law Experts on Issues Related to Takeover Bids, Bruxelles 2002.

9. Wertpapiererwerbs- und Übernahmegesetz od 20. prosinca 2001. (BGB1. I S. 3822) zadnji put mijenjan čl. 2c Zakona od 28. studenog 2012. (BGB1. I S. 2369).

10. Zakon o trgovačkim društvima (Narodne novine, br. 111/93, 34/99, 121/99, 52/00, 118/03, 107/07, 146/08, 137/09, 111/12, 125/11, 68/13, 110/15).

11. Zakon o tržištu kapitala (Narodne novine, br. 88/2008, 146/2008, 74/2009, 54/2013, $159 / 2013,18 / 2015,110 / 2015,123 / 2016,131 / 2017)$.

12. Zakon o preuzimanju dioničkih društava (Narodne novine, br. 109/07, 36/09, 108/12, 90/13 i 148/13).

\section{Literatura}

1. Čulinović-Herc, E., Zubović, A., Pravne značajke provedenih postupaka preuzimanja prije i nakon pristupanja u EU i uočena regulatorna pitanja, Zbornik Pravnog fakulteta u Zagrebu, 66, (5) str. 619-638 (2016).

2. Čulinović-Herc, E., Mikinac, O., Otvorena pitanja uvrštenih dioničkih društava: razlozi za i protiv povlačenja vrijednosnih papira s uvrštenja na uređenom tržištu, u: ČulinovićHerc, E., Jurić, D., Žunić Kovačević, N. (ur.), Zbornik radova s konferencije „Financiranje, upravljanje i restrukturiranje trgovačkih društava u doba recesije“, Rijeka, Pravni fakultet, 2011.

3. Ivkošić, M., Gubitak prava glasa - sankcija zbog povrede odredbi o obavješćivanju odnosno preuzimanju dioničkih društava, Zbornik susreta pravnika, Zagreb, 2017., str. 345-380.

4. Ivkošić, M., Obrana dioničkog društva od neprijateljskog preuzimanja, doktorski rad, Zagreb, 2013.

5. Hirte, H., Büllow, C. (ur.), Kölner Kommentar zum WpÜG, 2. izmjenjeno i dopunjeno izdanje, Köln, 2010.

6. Miladin, P., Trgovina financijskim instrumentima (vrijednosnim papirima, efektima), u: Miladin, P. (ur.) Prilagodba hrvatskog prava i ekonomije europskom tržištu kapitala, Zagreb, 2013., str. 527-561. 
7. Parać, Z., Dileme oko preuzimanja javnih dioničkih društava, Pravo u gospodarstvu 2003/4, str. 36-56.

8. Steinmeyer, R., WpÜG Wertpapiererwerbs- und Übernahmegesetz Kommentar, 3. potpuno izmijenjeno i dopunjeno izd., Berlin, 2013.

9. Zubović, A., Stjecanje glasačke kontrole nad uvrštenim društvom, doktorski rad, Zagreb, 2012.

10. Jurić, D., Zubović, A., Protuponuditeljske mjere i položaj uprave ciljnog društva u postupku preuzimanja ciljnog društva, Zbornik Pravnog fakulteta Sveučilišta u Rijeci, vol. 30., br. 1. 2009., str. 291-331. 


\title{
Petar Miladin*
}

\author{
Summary
}

\section{COUNTER-OFFER MEASURES ACCORDING TO THE DRAFT ACT ON AMENDMENTS TO THE ACT ON THE TAKEOVER OF JOINT-STOCK COMPANIES}

Law on taking over of joint stock companies (Official Gazzette, no. 109/07, 36/09, 108/12, 90/13 and 148/13, hereinafter ZPDD) requires to be reformed, and in any case it requires at least an open public discussion on the position of Board of Directors and Supervisory Board, respectively Management Board of the targeted joint stock company in the procedure of taking over the targeted company. Ministry of Finances established a Working group that discusses and prepares the Draft of the Law on amendments of the Law on taking over of the joint stock companies (Decision CLASS: 011-01/16-01/22 NUMBER: 513-06-03-16-2 of 5th May 2016, hereinafter: Working group). The author, as the member of the working group takes a stand on the reform of the law on taking over joint stock companies in the part that relates to undertaking the counter-offering measures in the procedure of taking over the joint stock companies and offers concrete suggestions de lege ferenda. The reasons for turn are based on the criticisms of strict neutral position of the Board of Directors and Supervisory Board of the targeted company de lege lata. The strict regulation of Art. 42. Par. 1. of ZPDD-a on so called neutral position of the Board of Directors and Supervisory Board of the targerted company in the procedure of taking over derogated the basic rule on business conduct of the company from Art. 252 of the Companies Act (Official Gazzette, no. 111/93, 34/99, 121/99, 52/00, 118/03, 107/07, 146/08, 137/09, 111/12, 125/11, 68/13, 110/15; hereinafter ZTD). The aforementioned rule should be therefore de lege ferenda changed so that the values of the domestic companies law and law governing capital markets, are in the gretest possible measure taken into account. Radical exclusion of the basic standard of conducting companies business in the procedure of taking over de lege lata is not justified. Particularly it is not appropriate from the position of weighing mutually conflicted political interests. The welfare of the targeted company must not be practicaly completely exterminated becaues of so called better interests of the law on taking over of joint stock companies. De lege lata welfare of the targeted company is not, and to say the least, valued enough in the procedure of taking over and in that respect solutions are offered de lege ferenda. Good example for necessary legal-political and positive legal turn is offered by the provisions of German Wertpapiererwerbs- und Übernahmegesetz (hereinafter WpÜG) which model the author took into account while offering solutions de lege ferenda. The Directive 2004/25 EU on takeover bids (hereinafter Directive 2004/25

* Petar Miladin, Ph. D., Full Professor, Faculty of Law, University of Zagreb; petar.miladin@, pravo.hr. 
EU) rests in that part on optional model.

Keywords: law of take-over of joint stock companies, counter offering measures, legal position of bord of directors and supervisory bord, principle of neutrality, bord of director's obligation to conduct company's business.

Zussamenfassung

\section{MASSNAHMEN HINSICHTLICH GEGENANGEBOTE GEMÄSS DER GESETZESVORLAGE ÜBER DIE ÄNDERUNGEN UND ERGÄNZUNGEN DES GESETZES ÜBER DIE ÜBERNAHME VON AKTIENGESELLSCHAFTEN}

Das Gesetz über die Übernahme von Aktiengesellschaften (Amtsblatt der Republik Kroatien, Nr. 109/07, 36/09, 108/12, 90/13 i 148/13, nachfolgend: GÜAG) verlangt eine Reform oder wenigstens eine öffentliche Konsultation über die Stellung des Vorstands und des Aufsichtsrates beziehungsweise des Verwaltungsrates der Zielaktiengesellschaft bei dem Übernahmeverfahren der Zielgesellschaft. Das Finanzministerium hat eine Arbeitsgruppe gegründet, welche über das Gesetz über die Änderungen und Ergänzungen des Gesetzes über die Übernahme von Aktiengesellschaften diskutiert und seine Vorlage vorbereitet (Beschluss, Klassifizierungsnummer: 011-01/16-01/22, Geschäftsnummer: 513-06-03-16-2 vom 5. Mai 2016, nachfolgend: Arbeitsgruppe). Der Autor ist als Mitglied dieser Arbeitsgruppe der Ansicht, dass das Recht über die Übernahme von Aktiengesellschaften im Bereich der Maßnahmen hinsichtlich Gegenangebote reformiert werden muss und bietet dafür konkrete Vorschläge. Solche Ansicht argumentiert man de lege lata durch die Kritik der strikten Neutralität des Vorstands und des Aufsichtsrates der Zielgesellschaft. Es wird betont, dass die strenge Bestimmung aus Art. 42 Abs. 1 des GÜAG über die sog. neutrale Stellung des Vorstands und des Aufsichtsrates der Zielgesellschaft bei dem Übernahmeverfahren die grundlegende Bestimmung über die Geschäftsführung aus Art. 252 des Gesetzes über Handelsgesellschaften derogiert hat (Amtsblatt der Republik Kroatien, Nr. 111/93, 34/99, 121/99, 52/00, 118/03, 107/07, 146/08, 137/09, 111/12, 125/11, 68/13, 110/15; nachfolgend: HGG). Deshalb sollte man die genannte Bestimmung ändern, um die Werte des heimischen Gesellschaftsrechtes und des Kapitalmarktrechtes anzuerkennen. Das radikale Ausschließen des grundlegenden Standards der Geschäftsführung kann man de lege lata nicht rechtfertigen. Ebenfalls ist das nicht angemessen hinsichtlich der Festsetzung von gegenseitigen rechtspolitischen Interessen. Das Wohl der Zielgesellschaft sollte wegen der unumgänglichen Interessen des Rechtes über die Übernahme von Aktiengesellschaften nicht geopfert werden. Das Wohl der Zielgesellschaft wurde bei dem Übernahmeverfahren de lege 
lata nicht genug bewertet, weshalb man in diesem Beitrag die Vorschläge de lege ferenda bietet. Das gute Beispiel dafür stellen die Bestimmungen des deutschen Wertpapiererwerbs- und Übernahmegesetzes (nachfolgend: WpÜG) dar, anhand welchem der Autor die Vorschlage de lege ferenda bietet. Die Richtlinie 2004/25/EG über die Übernahmeangebote (nachfolgend: Richtlinie 2004/25/ EG) stellt in dieser Hinsicht die andere Wahlmöglichkeit.

Schlüsselwörter: das Recht über die Übernahme von Aktiengesellschaften, Maßnahmen hinsichtlich Gegenangebote, rechtliche Stellung des Vorstands und des Aufsichtsrates, Neutralitätsgrundsatz, die Pflicht des Vorstands zur Geschäftsführung.

Riassunto

\section{LE MISURE DEL CONTRO PROPONENTE SECONDO IL DISEGNO DI LEGGE SULLE MODIFICHE ED INTEGRAZIONI DELLA LEGGE SUL RILEVAMENTO DELLE SOCIETÀ PER AZIONI}

La legge sul rilevamento delle società per azioni (Narodne novine, n. 109/07, 36/09, 108/12, 90/13 i 148/13, in avanti ZPDD) richiede una riforma, o perlomeno un dibattito aperto, sulla posizione dell'amministrazione e del collegio sindacale ovvero del consiglio di amministrazione della società per azioni nel corso della procedura di rilevamento. Il Ministero delle Finanze ha costituito un gruppo di lavoro che discute e prepara il disegno di legge sulle modifiche ed integrazioni della legge sul rilevamento delle società per azioni (Decisione Classe: 011-01/16-01/22 num. Ruolo: 513-06-0316-2 del 5 maggio 2016, in avanti gruppo di lavoro). L'autore in qualità di membro del gruppo di lavoro è dell'idea che sia necessaria una riforma del diritto al rilevamento delle società per azioni nella parte in cui si riferisce alle misure del contro proponente nella procedura di rilevamento delle società per azioni ed offre suggerimenti concreti. Le ragioni di un cambio di disciplina si fondano sulla critica rivolta alla posizione duramente neutrale dell'amministrazione e del collegio sindacale della società in questione de lege lata. Si osserva che la rigida regola dell'art. 42, comma 1 dello ZPDD sulla c.d. posizione neutrale dell'amministrazione e del collegio sindacale della società in occasione del rilevamento derogherebbe al principio generale sull'operato della società ai sensi dell'art. 252 della Legge sulle società commerciali (Narodne novine, n. 111/93, 34/99, 121/99, 52/00, 118/03, 107/07, 146/08, 137/09, 111/12, 125/11, 68/13, 110/15; in avanti ZTD). Detta regola va pertanto modificata al fine di consentire nella maggiore misura possibile i valori del diritto societario interno e del diritto interno del mercato finanziario. Un'esclusione radicale dello standard 
essenziale di conduzione degli affari della società in occasione del rilevamento de lege lata non è giustificato. In particolare, un tanto non è adeguato da una prospettiva di contemperamento degli interessi polito-giuridici contrapposti. Il benessere della società in questione non va del tutto annichilito in ragione dei preponderanti interessi legati al rilevamento della società. De lege lata Il benessere della società che va rilevata non è sufficientemente stimato nel procedimento di rilevamento e in tale senso si offrono alcune soluzioni de lege ferenda. Un buon esempio al fine di realizzare un cambio di direzione nella politica legislativa è offerto dalla disciplina del Wertpapiererwerbs- und Übernahmegesetz (in avanti WpÜG) tedesco in base al quale modello l'autore suggerisce soluzioni de lege ferenda. La direttiva 2004/25 EU concernente le offerte pubbliche di acquisto (in avanti Direttiva 2004/25 EU) si fonda in tale parte sul modello opzionale.

Parole chiave: diritto al rilevamento delle società per azioni, misure del contro proponente, posizione giuridica dell'amministrazione e del collegio sindacale, principio di neutralità, dovere dell'amministrazione di condurre gli affari della società. 